\title{
The taxonomic status and the geographical relationships of the Macaronesian endemic moss Fissidens luisieri (Fissidentaceae) based on DNA sequence data
}

\section{OlAF Werner}

Departamento de Biología Vegetal, Facultad de Biología, Universidad de Murcia, Campus de Espinardo, 30100 Murcia, Spain

e-mail: werner@um.es

\section{Jairo Patiño and Juana María González-Mancebo}

Departamento de Biología Vegetal (Botánica), Universidad de La Laguna, C/ Astrofísico Francisco Sánchez s/n, 38071 La Laguna, Tenerife, Islas Canarias, Spain e-mail: jpatino@ull.es; glezm@ull.es

\section{Rosalina Maria de Almeida Gabriel}

Departamento de Ciências Agrarias, CITAA, Universidade dos Açores, P-9702

Angra do Heroísmo Codex, Açores, Portugal

e-mail: rgabriel@uac.pt

\section{Rosa María Ros}

Departamento de Biología Vegetal, Facultad de Biología, Universidad de Murcia, Campus de Espinardo, 30100 Murcia, Spain

e-mail: rmros@um.es

\begin{abstract}
Aвstract. The taxonomic identity and the geographical relationships of the Macaronesian endemic moss Fissidens luisieri have been studied using the chloroplast $\operatorname{trn} \mathrm{G}_{\mathrm{UCC}}$ intron, the

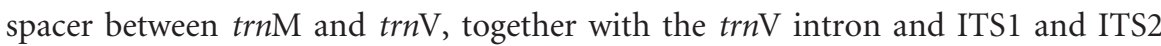
sequences. A comparison of F. luisieri with the most closely related species, F. serrulatus, from the same geographical areas reveals that the distribution pattern of F. serrulatus and F. luisieri, rather than their morphological differences, explains the observed differences. Therefore, we conclude that both names correspond to the same species. One of the primers for the chloroplast $\operatorname{trn}_{\mathrm{UCC}}$ intron and both primers for the $\operatorname{trn} \mathrm{M}-\operatorname{trn\mathrm {V}}$ region were designed for this study; they can all be widely used within bryophytes because they provide similar degrees of variability as other regions of the chloroplast genome such as the $a t p \mathrm{~B}-r b c \mathrm{~L}$ intergenic spacer.
\end{abstract}

KeYwords. Fissidens luisieri, Fissidens serrrulatus, Macaronesia, molecular analysis, taxonomy. 
Fissidens luisieri was described by Potier de la Varde (1955) from the Azores (São Miguel), using material collected in 1940 by Luisier. In the description, Potier de la Varde compared this species with F. polyphyllus and F. adianthoides. Later, a morphological study was carried out by Sérgio et al. (1997), comparing these three species with F. serrulatus and the Asiatic F. nobilis, all of which belong to sect. Serridium according to Iwatsuki and Inoue (1984). That section was later subsumed under the sect. Pachyfissidens, included in the subg. Pachyfissidens by Pursell and Bruggeman-Nannenga (2004).

Sérgio et al. (1997) provided a description and illustrations of both F. luisieri and F. serrulatus, and made a morphological comparison of all five species mentioned. According to these authors, the most important diagnostic characters to distinguish $F$. luisieri from $F$. serrulatus are the laminal cells and the leaf border, both of which can be better observed in cross-section. Fissidens luisieri has laminal cells in the median part of the leaf which are rectangularquadrate, smooth or with slightly convexly thickened walls, regularly arranged; a distinctly differentiated leaf border is translucent, yellow to orange or brown in older leaves and consists, in the upper half of the leaf, of 3-6(-8) rows of larger cells that are more or less prosenchymatous. In F. serrulatus the laminal cells are more or less polygonal, with high mammillae, irregularly arranged and generally shorter than in F. luisieri, and the leaf border is rarely colored, and consists of 3-5 rows of short rhomboidal cells that are less evident in cross-section. The marginal border of the vaginant lamina is entire in F. luisieri and serrulate in F. serrulatus. In addition to these characters, the exothecial cells in the capsule perimeter are more numerous in F. luisieri than in F. serrulatus.

Fissidens luisieri has been recorded in the Azores from Faial, São Miguel and Terceira (Gabriel et al. 2005; Sérgio et al. 1997), Pico (Frahm 2004) and São Jorge (Homem \& Gabriel 2008), in the Canary Islands in La Palma, La Gomera and Tenerife, and from Madeira (Sérgio et al. 1997). Despite the above mentioned morphological differences, identification problems have prevented us from knowing the real distribution of F. luisieri and F. serrulatus, at least in the Canaries. In intensive studies of laurel forest, only F. serrulatus was recorded (González-Mancebo \&
Hernández-García 1996; González-Mancebo et al. 2004; Losada-Lima et al. 1990, 1993). Nevertheless, revision of these specimens carried out during preparation of this paper, allowed to recognize both species following the criteria of Sérgio et al. (1997) and apparently no habitat differences could be found between them.

The goal of this study was to obtain DNA sequence information on the moss Fissidens luisieri, considered to be an endemic moss of the Macanoresian Region, unlike the broadly distributed F. serrulatus, and to make suggestions about its taxonomical status and geographical relationships. This article is integrated in two investigation projects that are intended to analyze the main biogeographical relationships of some Canarian and Macaronesian endemics based on DNA data, as well as to offer a taxonomic revision of the Canary Islands endemics.

\section{Material and Methods}

Plant material. Samples of six populations of Fissidens luisieri (from Azores, Canary Islands and Madeira) and six populations of F. serrulatus (from Azores, Canary Islands and Spanish mainland) were investigated for this study. To distinguish F. luisieri and F. serrulatus, we considered and measured all the diagnostic characters provided by Sérgio et al. (1997), although the characters of the sporophyte were not considered since they were not seen in most specimens. However, the overlaping and/or the noncoincidence of the possible combinations between some diagnostic characters hindered the use of some characters selected by these authors. Therefore, we chose as the best characters to distinguish F. luisieri and F. serrulatus the following: (i) leaf border (clearly differentiated vs. poorly differentiated), (ii) arrangement (regular vs. irregular) and (iii) shape (smooth-quadrate vs. mammillose-polygonal) of laminal cells in cross-section. Additionally, the marginal border of vaginant lamina (entire vs. serrulate) was also considered. Among these four characters, the first three were especially useful for distinguishing both Fissidens species due to the clear differences found. From our viewpoint, the rest of gametophyte characters were insufficiently discrete to separate the taxa. 
Fissidens osmundoides was chosen as the outgroup. In an initial phase of the project we tested other possible outgroup species that belong to the section Pachyfissidens and therefore are supposed to be closely related to F. luisieri, such as F. dubius, F. grandifrons, F. polyphyllus and F. taxifolius. However, ITS sequences did not allow a reliable alignment; besides it was impossible to obtain readable sequences of this region for selected species (e.g., F. polyphyllus). For this reason, these species were excluded from further analyses. Details of the origin of the plant material, vouchers and GenBank accession numbers of the obtained sequences are given in Table 1.

DNA isolation and amplification of ITS and chloroplast regions. Total DNA was extracted from dry material using the $\mathrm{NaOH}$ extraction method as explained in Werner et al. (2002). The chloroplast $\operatorname{trn} \mathrm{G}_{\mathrm{UCC}}$ intron was amplified in $50 \mu \mathrm{l}$ final volume with the primers trnGF (GGC TAA GGG TTA TAG TCG GC, presented here) and trnGR (GCG GGT ATA GTT TAG TGG, Pacak \& SzweykowskaKulińska 2000). The spacer between $\operatorname{trn} \mathrm{M}$ and $\operatorname{trn\mathrm {V}}$ together with the $t r n \mathrm{~V}$ intron were amplified using the primers trnMF (GCG ATA CTC TAA ACC ACT GAG) and trnVR (TYG AAC CGT AGA CAT TCT CGG). These primers were specifically designed for this study. PCR tests show that the primers can be broadly used within bryophytes and that the $\operatorname{trn} \mathrm{M}-\mathrm{V}$ region provides comparable variability to other noncoding regions of the chloroplast genome, such as the trn $\mathrm{G}$ intron or the atpB-rbcL intergenic spacer (Werner et al. unpublished data). ITS1 and ITS2 were amplified in separate reactions due to initial problems with some samples (especially those not recently collected) when trying to amplify the complete ITS1-5.8S-ITS2 region in one reaction. The primers used were 18F (GGA AAG AGA AGT CGT AAC AAG G) and 5.8SR (GCT GCG TTC TTC ATC GTT GC GCTGCGTTCTTCATCGATGC) for ITS1 and 5.8F (GCA ACG ATG AAG AAC GCA GC) and 25R (TCC TCC GCT TAG TGA TAT GC) for ITS2 (Stech \& Frahm 1999). Each reaction contained: $200 \mu \mathrm{M}$ of each dNTP, $2 \mathrm{mM} \mathrm{MgCl}_{2}, 2$ units of Taq polymerase (Oncor Appligene), $1 \mu$ BLOTTO (10\% skimmed milk powder and $0.2 \% \mathrm{NaN}_{3}$ in water) and the buffer provided by the enzyme supplier with $4 \mu \mathrm{l}$ of stock DNA added as template. BLOTTO has been shown to attenuate the PCR inhibition caused by plant compounds (De Boer et al. 1995). The amplification conditions were as follows: $3 \mathrm{~min}$ at $94^{\circ} \mathrm{C}, 35$ cycles of $30 \mathrm{sec}$ at $94^{\circ} \mathrm{C}, 30 \mathrm{sec}$ at $50^{\circ} \mathrm{C}$ and $1 \mathrm{~min}$ at $72^{\circ} \mathrm{C}$, and a final $7 \mathrm{~min}$ extension step at $72^{\circ} \mathrm{C}$. Amplification products were checked on $1 \%$ agarose gels and successful reactions were cleaned with the help of the GenElute PCR Clean-Up Kit (Sigma-Aldrich). Cycle sequencing was performed with the Big Dye Sequencing Kit (Perkin Elmer) using a standard protocol and the amplification primers. The annealing temperatures were set at $50^{\circ} \mathrm{C}$. The reaction products were separated on an ABI Prism 3700 automatic sequencer (Perkin Elmer).

Data analysis. The sequences were edited using Bioedit 5.0.9 (Hall 1999) and aligned manually. The alignment is available from the senior author on request and submitted to TreeBASE (SN 4137). The aligned sequences were analyzed using Maximum Parsimony (MP; Fitch 1971). Gaps were not treated as fifth character states but were recoded as present or absent with the help of SeqState (Müller 2005) using the modified complex coding option. The MP

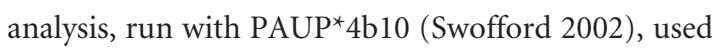
the following settings: RANDOM additions (100 replicates), TBR branch-swapping, MULTREES = yes, steepest descent $=$ no, COLLAPSE $=$ yes. The number of maxtrees (100) was not reached. All characters were equally weighted. A bootstrap analysis (Felsenstein 1985) with 1000 replicates was performed with the settings as mentioned. Additionally, a neighbor joining analysis was run using uncorrected pairwise distances. Branching confidence was assessed using 1000 bootstrap replicates. Additionally, the data were analyzed by Bayesian inference implemented with MrBayes 3.1 (Huelsenbeck \& Ronquist 2001; Ronquist \& Huelsenbeck 2003). The best models for nucleotide substitution were determined for each region with Modeltest (Posada \& Crandall 1998). Gaps were coded as explained above and treated as standard data. Each genomic region was allowed to evolve according to its own substitution model. Three runs were conducted with 2,000,000 generations. Trees were sampled every $100^{\text {th }}$ generation and the first 10,000 trees were discarded (burn-in) in order to 
o THE BRYOLOGIST 112(2): 2009

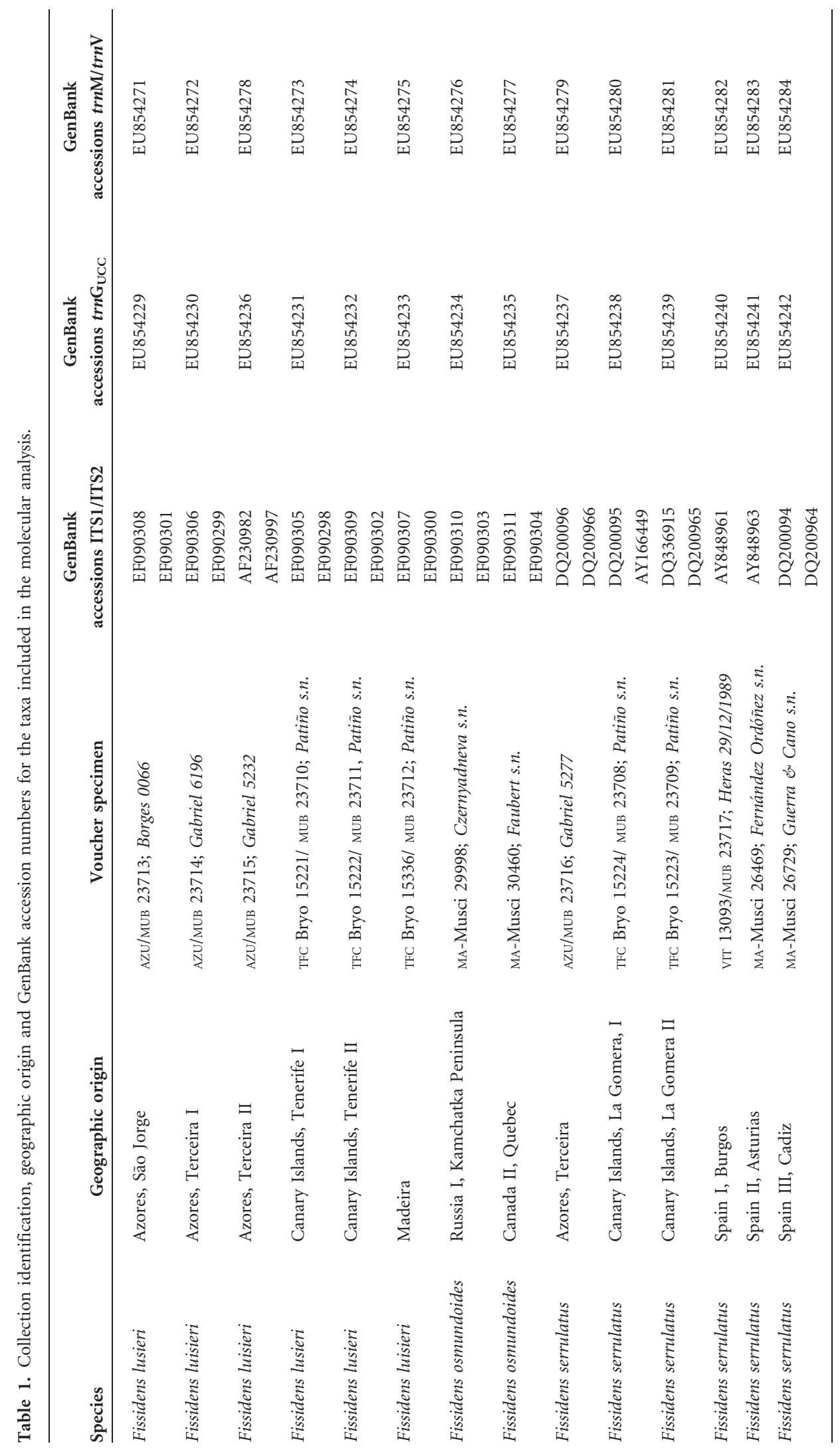


Table 2. Pairwise differences observed in the combined data set (ITS, $\operatorname{trn} \mathrm{G}$ intron, $\operatorname{trn} \mathrm{M}-\operatorname{trn} \mathrm{V}$ region). It is clearly visible that the variability within geografical regions (continental Spain/Canary Islands and Madeira/Azores) is low (values given in bold numbers) compared with the values between regions. The values do not reflect the hypothetical species limits.

$\begin{array}{lllllllllll}1 & 2 & 3 & 4 & 5 & 6 & 7 & 8 & 9 & 10 & 11\end{array}$

1. F. serrulatus Spain I

2. F. serrulatus Spain II

3. F. serrulatus Spain III

4. F. serrulatus La Gomera I

5. F. serrulatus La Gomera II

6. F. luisieri Tenerife I

7. F. luisieri Tenerife II

8. F. luisieri Madeira

9. F. luisieri Azores, São Jorge

10. F. luisieri Azores, Terceira I

11. F. luisieri Azores, Terceira II

12. F. serrulatus Azores, Terceira

$\begin{array}{rrrrrrrrrrr}\mathbf{1} & & & & & & & & & \\ \mathbf{0} & \mathbf{1} & & & & & & & & \\ 11 & 12 & 11 & & & & & & & \\ 11 & 12 & 11 & \mathbf{0} & & & & & & \\ 12 & 12 & 11 & \mathbf{3} & \mathbf{3} & & & & & & \\ 12 & 13 & 12 & \mathbf{3} & \mathbf{3} & \mathbf{0} & & & & & \\ 12 & 13 & 12 & \mathbf{3} & \mathbf{3} & \mathbf{2} & \mathbf{2} & & & & \\ 9 & 10 & 9 & 4 & 4 & 5 & 5 & 5 & & & \\ 10 & 11 & 10 & 5 & 5 & 6 & 6 & 6 & \mathbf{1} & & \\ 10 & 11 & 10 & 5 & 5 & 6 & 6 & 6 & \mathbf{1} & \mathbf{0} & \\ 10 & 11 & 10 & 5 & 5 & 6 & 6 & 6 & \mathbf{1} & \mathbf{0} & \mathbf{0}\end{array}$

exclude the trees before the chain reached the stationary phase.

A nested clade phylogeographic analysis (NCPA) was carried out in order to test the species status of different genetic lineages (Templeton 1998, 2001; Templeton et al. 1995). The entire procedure was run using ANeCA 1.2 (Panchal 2007). This program essentially provides a platform to run TCS (Clement et al. 2000) and GeoDis (Posada et al. 2000) in a userfriendly automated way. Gaps were not considered as fifth state but were recodified as " $\mathrm{A}$ " present or " $\mathrm{T}$ " absent. The connection limit was left at the default setting (95\%) and the automated inference key was used.

\section{Results}

There are large differences between possible outgroup species and the ingroup, especially for the nrITS sequences. As mentioned above, of various possible outgroup taxa, only Fissidens osmundoides could be reliably aligned with the ingroup. There are 16 variable positions between the two samples of this species. Of the F. luisieri-serrulatus samples, those from continental Spain were clearly different from the Macaronesian populations with 9-12 pairwise differences (mean 11.1). Within the Spanish mainland samples, we observed $0-1$ pairwise differences (mean 0.7), and within the Macaronesian samples we observed 0-6 pairwise differences (mean 3.7). When the Macaronesian samples were subdivided into two groups (Canary Islands and
Madeira versus Azores), the number of pairwise differences within each group fell to a maximum of three. The variability mainly corresponded to the nuclear ITS region. The continental samples of $F$. serrulatus had one mutation in common in each of the two investigated chloroplast regions that separated them from the Macaronesian populations. The number of pairwise differences corresponded clearly to a geographical pattern and not to the hypothetical species boundaries. Consequently, the mean value of pairwise distances between hypothetical F. luisieri and F. serrulatus was clearly lower than the differences between continental and island samples (6.9 vs. 11.1). Table 2 gives the pairwise distance of all individuals from both hypothetical species. These observations were further confirmed by the MP, NJ and Bayesian analyses. In the case of MP and NJ, the data clearly reflect the separation into two well-supported clades which separate the continental from the island samples (supported by bootstrap values in the range of $87-$ 100\%; Fig. 1). Within the Macaronesian clade, two subclades are visible, one including the specimens from the Azores, and the other one the CanarianMadeiran samples, although with slightly lower bootstrap support. Contrasting with these results, the Bayesian analysis does not support a separate island clade, but shows a polytomy resolving three clades: continental Spain, Azores and Canaries-Madeira.

The NPCA analysis reveals two significant fragmentations of the gene tree. The first one is 


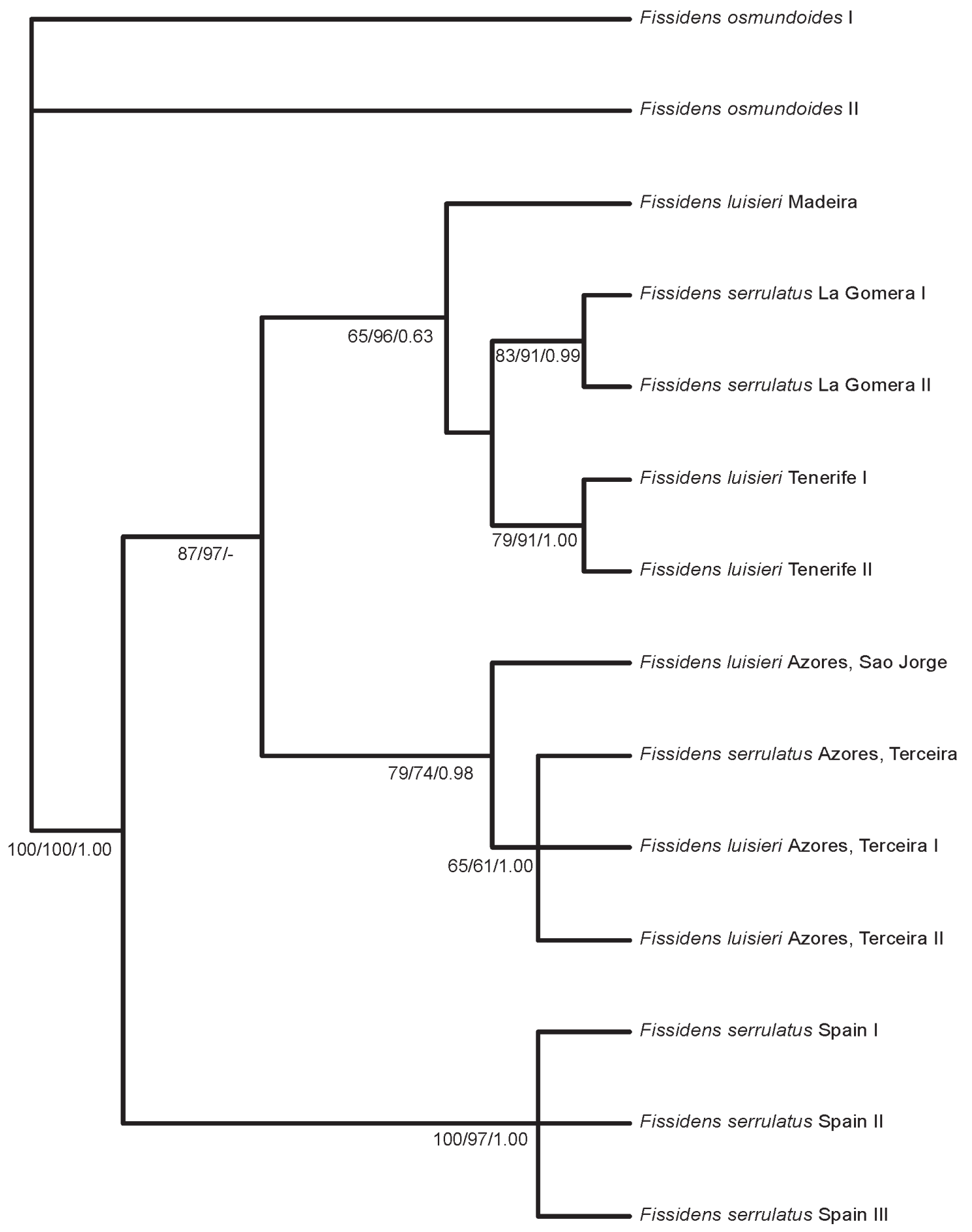

Figure 1. Strict consensus tree of three most parsimonious trees obtained $(\mathrm{RI}=1, \mathrm{CI}=1)$. Bootstrap support values (MP and NJ) and posterior probabilities (Bayes) are given below the branches. The branching pattern reflects the geographical origin of the samples and not the hypothetical species boundaries. 
found within clade 3-1 and separates the specimens of the Canarian-Madeiran-clade (2-1) from those of the Azores (clade 2-2). The second significant fragmentation separates the Macaronesian samples (clade 3-1) from the continental Spanish populations (clade 3-2). The nested clade cladogram with indications of the relevant subclades is given in Fig. 2. No indications of significant events along the hypothetical species boundaries between F. serrulatus and F. luisieri were found.

\section{Discussion}

The taxonomic value of many subtle differences between hypothetical bryophyte species is often difficult to assess. Recent studies using molecular methods have been of great value in clarifying cases where morphology alone could not provide broadly acceptable solutions. To cite just one example, based on nrITS sequences, Heinrichs et al. (2004) proposed a broad species concept in the case of Plagiochila bifaria, treating $P$. centrifuga and $P$. commpressula as synonyms. On the other hand, molecular data led to the discovery of new species that are almost impossible to distinguish on a morphological basis. One of the first cases of cryptic species in bryophytes detected by molecular data was Conocephalum conicum (Szweykowski \& Krzakowa 1979). Later studies found slight morphological differences between the two cryptic species present in Europe and led to the formal description of a new species, Conocephalum salebrosum (Szweykowski et al. 2005). But even if a morphological character is confirmed to be valid for distinguishing between two species, in other cases the same character may be useless. This is, for example, the case of the bistratose leaf margins, which define Tortula schimperi, a species confirmed by nrITS sequence data (Cano et al. 2005), but that seems to be of no importance in the case of Platyhypnidium torrenticola, a species recently synonymized with $P$. riparioides (Werner et al. 2007). Similarly, a character that differentiates Tortula mucronifolia from other closely related species is the absence of papillae on the leaf surface. Molecular data show that this species is clearly separated from other species of the Tortula subulata complex, with which it shares a close similarity in other morphological characteristics (Cano et al. 2005). In contrast, the leaf surface was very variable in other cases, where papilla variability in Barbula indica was surveyed from a morphological and molecular viewpoint (Werner et al. 2003). It was observed that Barbula indica varies greatly as regards the number, shape and size of its papillae.

In the present case, the cladograms based on MP, $\mathrm{NJ}$ and Bayesian Inference clearly reflect the geographic origin of the samples, but not the hypothetical membership of one of the two species, Fissidens luisieri or F. serrulatus. Furthermore, the morphological differentiation of both species is weak. From all the characters proposed as diagnostic by Sérgio et al. (1997) the only consistent ones were those observed in the cross-section of the lamina: the leaf border, and the arrangement and the shape of the laminal cells. Nevertheless the distinction of both species based on these characters is not supported by the molecular data.

There is no universally accepted species concept, and possibly there never will be, due to the diversity of biological problems, realities and complications related with the speciation process (Hull 1997). In this case, we use the cohesion species concept to test the status of Fissidens luisieri because it offers the advantage that species can be identified with objective, a priori criteria with an inference procedure that automatically yields insight into the process of speciation (Templeton 2001). The most relevant processes that the applied ANeCA software (Panchal 2007) discovered were fragmentation events, which are clearly related to the geographic isolation of the populations. The results of the NCPA would allow the recognition of several species along the geographical borders. But, as mentioned above, there are no consistent morphological characters that permit the separation of these species without taking into consideration the sequences. Our final conclusion is that F. luisieri should be formally synonymyzed with $F$. serrulatus.

As the sequence divergence between the different locations is relatively high, the clear geographical signal obtained in the F. luisieri-serrulatus complex might indicate that the dispersal potential of Fissidens is reduced compared with other genera like Leucodon (manuscript in preparation) and Platyhypnidium that show almost no nrDNA variation (Werner et al. 2007). Freitas and Brehm (2001) studying Porella 


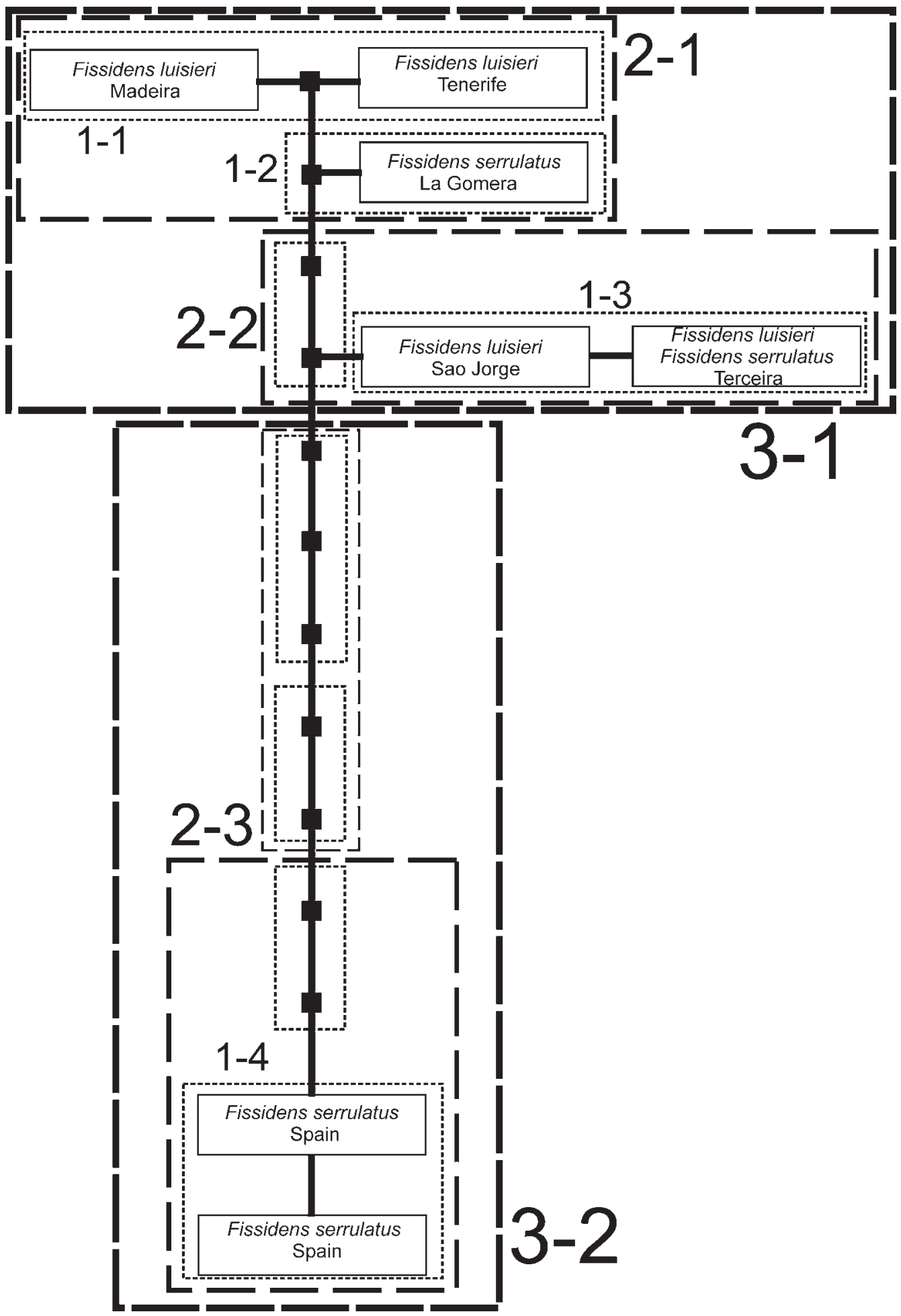

Figure 2. Haplotype tree and nested clade design for the combined ITS-cpDNA data. The first number of the clades indicates the step-length (one-, two- or three-step clades). Hypothetical intermediate haplotypes that were not actually found are given as black squares. Fragmentation occurs between subclades 2-1 and 2-2, separating Canary Islands and Madeira from the Azores, and between clade 3-1 and 3-2, separating the island specimens from the Spanish mainland samples. 
canariensis also concluded that the lack of substantial spore dispersal in the species justifies the differences of the RAPD markers between populations of the different Macaronesian archipelagos. Alternatively higher evolutionary rates combined with high sexual reproduction could explain the results. Future studies on other Fissidens species will be interesting in this respect. The number of pairwise differences between the two populations of F. osmundoides, for example, is higher than that observed within the ingroup. Therefore, the sequence variability observed in the $F$. luisieri-serrulatus complex seems to be in the normal range of this genus.

To our knowledge, this is the first record of using of the trn $\mathrm{M}-t r n \mathrm{~V}$ region for a taxonomic study in bryophytes. The observed variability was low for the purposes of this study, but was similar to that observed in the $\operatorname{trn} \mathrm{G}$ intron. The $\operatorname{trn} \mathrm{G}$ intron has been very useful in many previous studies, because there are universal primers available and because of its relative high variability compared with other chloroplast regions. Ongoing work using the primers presented here shows that our primers work in other bryophytes as well, for example Didymodon (Pottiaceae) and Orthotrichum (Orthotrichaceae), and that the sequence variability found in this region is comparable to regions like the $a t p \mathrm{~B}-r b c \mathrm{~L}$ spacer or the $t r n \mathrm{G}$ intron. Consequently, this primer pair might be useful for other studies investigating taxonomic questions at genus or family level in bryophytes.

\section{TAXONOMY}

Fissidens serrulatus Brid., Muscol. Recent. Suppl. 1: 170. 1806.

Fissidens luisieri P. de la Varde, Mitt. Thüring. Bot. Ges. 1(2/3): 15, figs. 1-5. 1955. Type: [PortugaL] ARChipel DES AZOrEs: île San Miguel, Tameyal (Tafsmujal), Mar 1940, A. Luisier (PC), syn. nov.

\footnotetext{
ACKNOWLEDGMENTS

We thank the curators of MA and VIT for sending material, and Terry Hedderson and Dietmar Quandt for their helpful comments on an earlier version of the manuscript. This work was carried out with financial support from the Spanish Ministerio de Educación y Ciencia (CGL2005-00028), Ministerio de Medio Ambiente (129/2006) and the Canary Islands Government (P1042004-028), who also funded a predoctoral grant to JP (TES2005/086).
}

\section{Literature Cited}

Cano, M. J., O. Werner \& J. Guerra. 2005. A morphometric and molecular study in Tortula subulata complex (Pottiaceae, Bryophyta). Botanical Journal of the Linnean Society. London 149: 333-350.

Clement, M., D. Posada \& K. A. Crandall. 2000. TCS: A computer program to estimate gene genealogies. Molecular Ecology 9: 1657-1659.

De Boer, S. H., L. J. Ward, X. Li \& S. Chittaranjan. 1995. Attenuation of PCR inhibition in the presence of plant compounds by addition of BLOTTO. Nucleic Acids Research 23: 2567-2568.

Felsenstein, J. 1985. Confidence limits on phylogenies: an approach using the bootstrap. Evolution 39: 783-791.

Fitch, W. M. 1971. Toward defining the course of evolution: minimum change for a specific tree topology. Systematic Zoology 20: 406-416.

Frahm, J.-P. 2004. A guide to bryological hotspots in Europe. Archive for Bryology 3: 4-14.

Freitas, H. \& A. Brehm. 2001. Genetic diversity of the Macarnesian leafy liverwort Porella canariensis inferred from RAPD markers. Journal of Heredity 92: 339-345.

Gabriel, R., E. Sjögren, R. Schumacker, C. Sérgio, J.-P. Frahm \& E. Sousa. 2005. List of bryophytes. Pages 117-133. In P. A. V. Borges, R. Cunha, R. Gabriel, A. M. F. Martins, L. Silva \& V. Vieira (eds.), A List of the Terrestrial Fauna (Mollusca and Arthropoda) and Flora (Bryophyta, Pteridophyta and Spermatophyta) from the Azores. Direcção Regional de Ambiente e do Mar dos Açores and Universidade dos Açores, Horta, Angra do Heroísmo and Ponta Delgada. González-Mancebo, J. M. \& C. D. Hernández-García. 1996. Bryophyte life strategies along an altitudinal gradient in $\mathrm{El}$ Canal y Los Tiles (La Palma, Canary Islands). Journal of Bryology 19: 243-255.

—, A. Losada-Lima \& J. Patiño Llorente. 2004. Forest floor bryophytes of laurel forest in Gomera (Canary Islands): Life strategies and influence of the tree species. Lindbergia 29: $5-16$.

Hall, T. A. 1999. BioEdit: a user-friendly biological sequence alignment editor and analysis program for Windows 95/98/ NT. Nucleic Acids Symposium Series 41: 95-98.

Heinrichs, J., H. Groth, M. Lindner, K. Feldberg \& D. S. Rycroft. 2004. Molecular, morphological, and phytochemical evidence for a broad species concept in Plagiochila bifaria (Hepaticae). The Bryologist 107: 28-40.

Homem, H. \& R. Gabriel. 2008. Briófitos Raros dos Açores. Princípia Editora, Lda. Estoril.

Huelsenbeck, J. P. \& F. Ronquist. 2001. MRBAYES: Bayesian inference of phylogeny. Bioinformatics 17: 754-755.

Hull, D. L. 1997. The ideal species concept-and why we can't get it. Pages 357-380. In M. F. Claridge, H. A. Dawah \& M. R. Wilson (eds.), Species: The Units of Biodiversity. Chapman \& Hall, London. 
Iwatsuki, Z. \& S. Inoue. 1984. Cytotaxonomic studies on the Japanese species of Fissidens Hedw. (Musci). Journal of the Hattori Botanical Laboratory 57: 343-362.

Losada-Lima, A., J. M. González-Mancebo \& E. Beltrán-Tejera. 1993. Contribution to the bryological knowledge of the Reserve of the Biosphere "El Canal y Los Tiles" (La Palma, Canary Islands). Courier Forschungsinstitut Senckenberg 159: 195-198.

$\longrightarrow,-$ M. B. Febles-Padilla, E. Beltrán-Tejera, M. C. León-Arencibia \& A. Bañares-Baudet. 1990. Contribución al conocimiento de la flora briológica del Monte de Aguas y Pasos (Los Silos, Tenerife). II. Briófitos saxícolas y terrícolas. Vieraea 19: 11-18.

Müller, K. 2005. SeqState-primer design and sequence statistics for phylogenetic DNA data sets. Applied Bioinformatics 4: 65-69.

Pacak, A. \& Z. Szweykowska-Kulińska. 2000. Molecular data concerning alloploid character and the origin of chloroplast and mitochondrial genomes in the liverwort Pellia borealis. Journal of Plant Biotechnology 2: 101-108.

Panchal, M. 2007. The automation of nested clade phylogeographic analysis. Bioinformatics 23: 509-510.

Posada, D. \& K. A. Crandall. 1998. Modeltest: testing the model of DNA substitution. Bioinformatics 14: 817-818. \& A. R. Templeton. 2000. GeoDis: A program for the cladistic nested analysis of the geographical distribution of genetic haplotypes. Molecular Ecology 9: 487-488.

Potier de la Varde, R. 1955. Nouveau Fissidens aux Azores. Mitteilungen der Thüringischen Botanischen Gesellschaft 1: $15-16$.

Pursell, R. A. \& M. A. Bruggeman-Nannenga. 2004. A revision of the infrageneric taxa of Fissidens. The Bryologist 107: $1-20$.

Ronquist, F. \& J. P. Huelsenbeck. 2003. MRBAYES 3: Bayesian phylogenetic inference under mixed models. Bioinformatics 19: 1572-1574.

Sérgio, C., Z. Iwatsuki \& A. Ederra. 1997. Fissidens luisieri P. Varde (Fissidentaceae, Musci), a neglected species from Macaronesia. Journal of the Hattori Botanical Laboratory 83: 237-249.
Stech, M. \& J.-P. Frahm. 1999. The status of Platyhypnidium mutatum Ochyra \& Vanderpoorten and the systematic value of the Donrichardsiaceae based on molecular data. Journal of Bryology 21: 191-195.

Swofford, D. L. 2002. PAUP ${ }^{\star} 4$ b10. Phylogenetic Analysis Using Parsimony ( ${ }^{*}$ and Other Methods). Version 4b10. Sinauer Associates, Sunderland, Massachusetts.

Szweykowski, J., K. Buczkowska \& I. J. Odrzykoski. 2005. Conocephalum salebrosum (Marchantiopsida, Conocephalaceae) - a new Holarctic liverwort species. Plant Systematics and Evolution 253: 133-158.

\& \& M. Krzakowa. 1979. Variation of four enzyme systems in Polish populations of Conocephalum conicum (L.) Dumort. (Hepaticae, Marchantiales). Bulletin de l'Académie Polonaise des Sciences, Série des Sciences Biologiques 27: 37-41.

Templeton, A. R. 1998. Nested clade analyses of phylogeographic data: testing hypotheses about gene flow and population history. Molecular Ecology 7: 381-397.

- 2001. Using phylogeographic analyses of gene trees to test species status and processes. Molecular Ecology 10: 779-791.

—_, E. Routman \& C. Phillips. 1995. Separating population structure from population history: a cladistic analysis of the geographical distribution of mitochondrial DNA haplotypes in the tiger salamander, Ambystoma tigrinum. Genetics 140: 767-782.

Werner, O., J. Patiño, J. M. González-Mancebo \& R. M. Ros. 2007. The taxonomic status of Platyhypnidium torrenticola based on ITS sequence data. Cryptogamie, Bryologie 28: 187-195.

\& J. Guerra. 2002. Direct amplification and $\mathrm{NaOH}$ extraction: two rapid and simple methods for preparing bryophyte DNA for polymerase chain reaction (PCR). Journal of Bryology 24: 127-131.

\& J. M. González-Mancebo. 2003. The variability of the papillae on the lamina of Barbula indica (Hook.) Spreng. (Pottiaceae, Musci): a morphological and molecular approach. Cryptogamie, Bryologie 24: 367-375.

ms. received March 10, 2008; accepted November 3, 2008. 